\title{
Focus Group Discussion Tindak Pidana Destructive Fishing dan Dampaknya terhadap Keberlanjutan Pariwisata Bahari Kabupaten Pesawaran
}

\author{
Maya Shafira ${ }^{1}$, Eddy Rifai ${ }^{2}$, Diah Gustiniati ${ }^{3}$, Mashuril Anwar ${ }^{4}$ Rosa Linda ${ }^{5}$ \\ Universitas Lampung, Jl. Prof. Dr. Ir. Sumantri Brojonegoro, Gedong Meneng, Kec. Rajabasa, \\ Kota Bandar Lampung, Lampung 35141 1,2,3,45 \\ Email: maya.shafira@fh.unila.ac.id ${ }^{1 *}$
}

(Diajukan: 22 September 2021, Direvisi: 10 Oktober 2021, Diterima: 12 Januari 2022)

\begin{abstract}
ABSTRAK
Kegiatan ini bertujuan untuk mengedukasi mitra dalam hal ini Dinas Pariwisata Kabupaten Pesawaran, mengenai regulasi dan dampak tindak pidana destructive fishing terhadap pengelolaan pariwisata bahari yang berkelanjutan. Metode yang digunakan dalam pencapaian tujuan tersebut yakni obesevasi secara langsung dengan penyampaian materi melalui ceramah, diskusi terarah dan tanya jawab. Permasalahan dalam pengambdian ini adalah adanya ketidakberlanjutan dan terganggunya perkembangan pariwisata dari beberapa dimensi terutama yang terkait lingkungan yang terjadi akibat adanya aktivitas destructive fishing. Dalamh pelaksanaan kegiatan, diketahui bahwa Kabupaten Pesawaran memiliki beberapa kawasan wisata yang berbasis pantai, kuliner, kerajinan, kawasan wisata berbasis bahari dan warisan budaya, serta kawasan wisata berbasis air terjun. Tindak pidana destructive fishing akan berdampak terhadap keberlanjutan sektor pariwisata di Kabupaten Pesawaran, sebab kerusakan ekosistem akan menyebabkan pada berbagai identitas laut yang mengurangi daya tarik pariwisata. Oleh sebab itu tim pengambdian masyarakat Fakultas Hukum Universitas Lampung berusaha memberikan pemahaman atau edukasi kepada Dinas Pariwisata Kabupaten Pesawaran dan masyarakat nelayan mengenai dampak destructive fishing terhadap keberlanjutan ekosistem di perairan dan pariwisata bahari, memberikan pemahaman mengenai peraturan, pengawasan dan pengelolaan pariwisata bahari yang berkelanjutan, dan memberikan pengetahuan terkait teknologi penangkapan ikan ramah lingkungan. Masukan dari berbagai kegiatan ini terkait penanggulangan tindak pidana destructive fishing, guna keberlanjutan penngelolaan pariwisata bahari di Kabupaten Pesawaran.
\end{abstract}

Kata kunci: Destructive fishing; Pariwisata bahari; Kabupaten Pesawaran.

\begin{abstract}
This service aims to educate partners, in this case the Pesawaran Regency Tourism Office, regarding regulations and the impact of the criminal act of destructive fishing on sustainable marine tourism management. The method used in achieving these goals is direct observation with the delivery of material through lectures, focused discussions and questions and answers. The problem in this service is the unsustainability and disruption of tourism development from several dimensions, especially those related to the environment that occur due to destructive fishing activities. In carrying out the activities, it is known that Pesawaran Regency has several beach-based tourism areas, culinary, handicrafts, marine-based tourism areas and cultural heritage, as well as waterfall-based tourist areas. The crime of destructive fishing will have an impact on the sustainability of the tourism sector in Pesawaran Regency, because damage to the ecosystem will cause various marine identities that reduce tourism attractiveness. Therefore, the community service team at the Faculty of Law, University of Lampung, seeks to provide understanding or education to the Pesawaran Regency Tourism Office and fishing communities regarding the impact of destructive fishing on ecosystem sustainability in waters and marine tourism, providing an understanding of regulations, supervision and management of sustainable marine tourism, and provide knowledge related to
\end{abstract}


environmentally friendly fishing technology. The input from these various activities is related to the prevention of destructive fishing, in order to sustain the management of marine tourism in Pesawaran Regency.

\section{Keywords: Destructive fishing; Maritime tourism; Pesawaran regency}

\section{PENDAHULUAN}

Kabupaten Pesawaran memiliki potensi penting guna mengembangkan wisata bahari sebab Teluk Rati yang berbatasan secara langsung, hal ini membuat sumber daya alam memiliki potensi alam yakni pantai mangrove, berpasir, dan jasa-jasa lingkungan lain yang memiliki kemampuan dalam pengembangan wisata bahari yakni seperti wisata mangrove, wisata pantai, dan wisata bahari yang banyak dan unik. Garis pantai sepanjang $96 \mathrm{~km}$ yang dimiliki oleh Kabupaten Pesawaran, terbagi menjadi beberapa yakni Selat Sunda yang berbatasan langsung dengan Teluk Rantai serta mempyunyai gugus pulau-pulau sebanyak 37 pulau. Gugus pulau ini menyebar di berbagai wilayah yakni di Kecamatan Marga Punduh, Teluk Pandan, Padang Cermin dan Punduh Pidada,. Kabupaten Pesawaran mempunyai keunggulan wisata bahari melalui keindahan identitas bawah laut yang penting untuk dilakukan pengembangan (Alvi, 2018). Pada Tahun 2016 menurut data dari dinas pariwisata, bahwa terdapat 24 obyek wisata bahari yang menyebar diberbagai gugus-gugus pulau yang terdapat pada Kabupaten Pesawaran.

Sampai saat ini, beberapa obyek pariwisata bahari di Kabupaten Pesawaran terus memperlihatkan beberapa permasalahan yang membuktikan bahwa terdapat gangguan perkembangan pariwisata serta ketidakberlanjutan dari beberapa sisi terutama yang berkaitan dengan lingkungan mengakibatkan terjadinya aktivitas destructive fishing. Kawasan perairan Pulau Tegal dan Sidodadi merupakan bagian dari wilayah perairan Teluk Lampung yang berada di Kabupaten Pesawaran Kecamatan Padang Cermin Provinsi Lampung memiliki segenap potensi yang telah menjadi daya tarik berbagai pemilik kepentingan guna melaksanakan kegiatan eksploitasi sesuai dengan kepentingan masingmasing. Salah satu dampak negatif yang mengemuka dan perlu mendapat perhatian akibat berlangsungnya kegiatan eksploitasi tersebut adalah ancaman terhadap perkembangan dan keberlanjutan pariwisata bahari Kabupaten Pesawaran.

Ancaman tersebut dapat berasal dari kegiatan budidaya dan penangkapan ikan yang merusak (destructive fishing). Selain itu sebagaimana melalui RIPPDA Kabupaten Pesawaran 2017-2031 (Dinas Pariwisata Kabupaten Pesawaran, 2015) yang oleh Dinas Pariwisata menyatakan bahwa Pulau Pahawang telah mengalami kerusakan alam yang 
terbukti dengan adanya penurunan kondisi terumbu karang. Saat ini, terumbu karang yang mempunyai 1.673,063 Ha terdapat di laut Kabupaten Pesawaran, hanya 22,22\% atau 371.79 Ha yang berkondisi baik, sementara seluas 743,5856 Ha atau 44,44\% berkondisi cukup baik, dan sisanya 557,69 Ha atau 33,34\% mempunyai kondisi yang sudah tidak baik (Hall, 1999).

Kegiatan destructive fishing merupakan kegiatan yang dimana seseorang menggunakan bahan peledak atau bom ikan dalam melakukan kegiatannya. Bahan peledak yang digunakan adalah bom buatan sendiri yang dilakukan dengan prosedur menyiapkan bubuk di dalam minuman ringan atau botol bir. Pembuatan sumbu melalui kepala korek yang digerus dan kemudian dimasukan pada suatu pipa yang sempit, selanjutnya diikat kuat dengan kawat. Menyalakan sumbu kemudian botol dilempar kedala air (Musdalifah, 2017). Apabila situasi seperti ini tidak di tindak lanjuti, maka akan terjadi penurunan daya saing dan citra wisata bahari Kabupaten Pesawaran. Upaya untuk mencegah terjadinya disfungsi kawasan dan degradasi disfungsi kawasan wisata bahari di Kabupaten Pesawaran akibat aktivitas destructive fishing, maka penting guna memberikan penjelasan kepada Dinas Pariwisata Kabupaten Pesawaran dan masyarakat guna berperan aktif untuk mengimplementasikan dalam mengembangkan wisata bahari di Kabupaten Pesawaran secara teratur, tersistematis dan berkelanjutan dengan mengikutserakan seluruh elemen atau bagian stakeholder yang mempunyai peranan di kawasan pesisir hingga mendapatkan memanfaatkan aset yang ada secara maksimal.

Permasalahan yang terjadi di wilayah Pesawaran ini merupakan permasalahan yang besar, saat ini kegiatan penangkapan ikan dengan menggunakan bahan, alat atau cara yang merusak sumber daya ikan maupun lingkungannya, seperti menggunakan bahan peledak, bahan beracun,setrum, dan alat tangkap lainnya yang tidak ramah lingkungan. Kegiatan destructive fishing ini dilarang karena merupakan salah satu ancaman utama terhadap pengelolaan potensi perikanan Indonesia selain Illegal Fishing. Untuk itu kegiatan penangkapan ikan seperti ini harus diatasi dengan memberikan edukasi kepada nelayan dan masyarakat setempat. Jika tidak diselesaikan, maka hal ini akan berdampak buruk pada keberlanjutan ekosistem di perairan dan pariwisata bahari.

Masalah yang selalu di hadapi oleh kolaborator dan disetujui oleh tim pengusul guna diberikan penanggulangan yakni minimnya pengetahuan masyarakat terkait dampak destructive fishing terhadap berkesinambungannya dan ekosistem pada pariwisata bahari dan perairan, kurangnya pemahaman terkait peraturan, pengelolaan dan pengawasan pariwisata bahari yang berkesinambungan, serta masyarakat belum paham terkait 
teknologi untuk menangkap ikan yang ramah lingkungan. Oleh karena itu, kegiatan ini bertujuan mengedukasi mitra dalam hal ini Dinas Pariwisata Kabupaten Pesawaran, mengenai regulasi dan dampak tindak pidana destructive fishing terhadap pengelolaan pariwisata bahari yang berkelanjutan.

\section{METODE}

Metode yang digunakan dalam mengatasi permasalahan mitra yakni penyampaian materi melalui ceramah, diskusi terarah dan tanya jawab. Penyampaian materi oleh tim dialukan dengan metode ceramah LCD yang telah dipersiapankan sebelumnya. Secara keseluruhan kegiatan pengabdian yang dilaksanakan di Dinas Pariwisata Kabupaten Pesawaran ini dilaksanakan melalui tahapan-tahapan sebagai berikut:

1. Tahap Persiapan, persiapan dilakukan selama 7 hari kerja dengan kegiatan mempersiapkan administrasi kegiatan seperti surat perizinan dan perlengkapan lainnya, menggandakan materi kegiatan, daftar pertanyaan, peninjauan ke lokasi kegiatan termasuk pula pendekatan sosial kepada Lurah Kelurahan Kangkung, Camat Teluk Betung Selatan, dan masyarakat nelayan gudang lelang Bandar Lampung.

2. Tahap Pelaksanaan, kegiatan penyuluhan ini dilakukan selama 1 hari dengan tahapan kegiatan sebagai berikut:
a. Melaksanakan evaluasi awal (Pre-Test);
b. Penyampaian materi kegiatan;
c. Diskusi terarah dan tanya jawab;
d. Pelayanan klinis;
e. Melaksanakan evaluasi akhir (Post-Test).

Kegiatan berlokasi di Dinas Pariwisata Kabupaten Pesawaran, dilaksanakan pada hari Rabu, 30 Juni Tahun 2021 Pukul 10.00 WIB s/d selesai. Kegiatan pengabdian kepada masyarakat dilaksanakan oleh Maya Shafira, S.H., M.H. selaku ketua pelaksana, Dr. Eddy Rifai, S.H., M.H. dan Diah Gustiniati, S.H., M.H. selaku anggota dan 2 mahasiswa yang terlibat. Kegiatan ini diikuti oleh 27 (dua puluh tujuh) orang peserta yang terdiri dari pegawai dan staf Dinas Pariwisata Kabupaten Pesawaran. Adapun narasumber kegiatan ini terdiri dari unsur Dinas Kelautan dan Perikanan Provinsi Lampung, Dinas Pariwisata Kabupaten Pesawaran, BAPPEDA Kabupaten Pesawaran, Dinas Perikanan Kabupaten Pesawaran, dan Dinas Lingkungan Hidup Kabupaten Pesawaran. 


\section{HASIL, PEMBAHASAN, DAN DAMPAK Pelaksanaan Kegiatan}

Kegiatan yang berlokasi di Kabupaten Pesawaran tepatnya di Dinas Pariwisata ini dilaksanakan pada hari Rabu, 30 Juni Tahun 2021 Pukul 10.00 WIB s/d selesai. Pemateri atau narasumber dalamacara ini adalah dari berbagai bagian, yaitu Dinas Kelautan dan Perikanan Provinsi Lampung, Dinas Pariwisata Kabupaten Pesawaran, BAPPEDA Kabupaten Pesawaran, Dinas Perikanan Kabupaten Pesawaran, dan Dinas Lingkungan Hidup Kabupaten Pesawaran.

Pelaksanaan kegiatan pengabdian kepada masyarakat dilakukan dengan mematuhi protokol kesehatan secara ketat. Sebelum memasuki ruangan, para peserta dianjurkan memakai masker, hand sanitizer, dan mengisi daftar hadir. Selain itu, jumlah peserta juga dibatasai hanya $50 \%$ dari kapasitias ruangan.

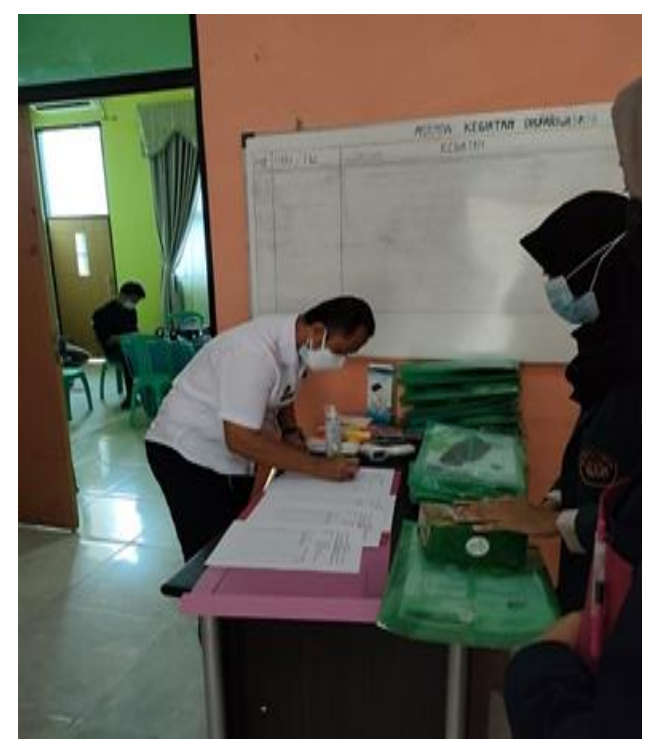

Gambar 1. Peserta mengisi daftar hadir

Setelah semua peserta dikondisikan di dalam ruangan, acara dipandu oleh pembawa acara. Acara diawali dengan pembukaan, menyanyikan lagu kebangsaan Indonesia Raya, menyanyikan himne Kabupaten Pesawaran, sambutan-sambutan, dan doa. Berikutnya dilanjutkan dengan sesi penyampaian materi dari masing-masing narasumber, diskusi dan tanya jawab. 


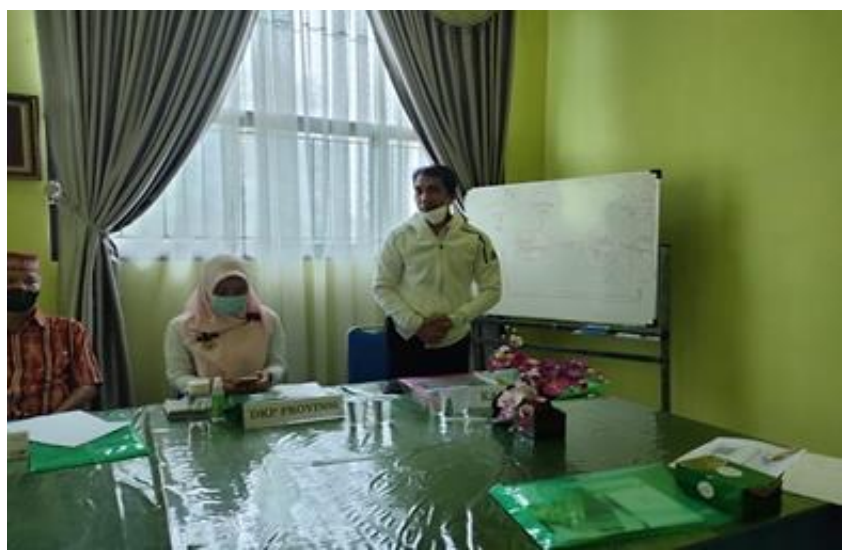

Gambar 2. Sambutan Kepala Dinas Pariwisata Kabupaten Pesawaran

\section{Analisis Hasil dan Capaian Kegiatan}

Penataan Kabupaten Pesawaran yang sesuai dengan dokumen penataan yang menjelaskan tujuan dari penataan ruang Kabupaten Pesawaran adalah tercapainya Kabupaten Pesawaran yang sejahtera berbasiskan sektor industri, agro dan pariwisata. Definisi dari sejahtera dalam Rencana Tata Ruang Wilayah (RTRW) Kabupaten Pesawaran tersebut adalah memberi peningkatan untuk masyarakat yang tercermin dari tercukupinya sarana dan prasarana pendidikan, perdagang maju, kesehatan, sejahtera serta bercirikan sektor industri dan jasa serta sarana dan prasarana lainnya lainnya. Sedangkan penjelasan pariwisata dalam peningkatan kesejahteraan meliputi kegiatan melindungi dan memanfaatkan sumber daya kelautan yang terus dan berkesinambungan serta mempunyai kualitas, seperti budidaya tambak, budidaya laut, perikanan tangkap, budidaya laut, serta industri pengolahan hasil laut, pariwisata dan transportasi (Nurhasanah, 2017).

Berdasarkan pemaparan Bapak Elsafri Fahrizal, S.H., M.Si. sebagai kepala Dinas Pariwisata Kabupaten Pesawaran, termasuk dalam pemateri kegiatan, Kabupaten pesawaran memiliki beberapa kawasan wisata yang bercirikan pantai, kerajinan, kuliner; kawasan wisata bercirikan bahari, kawasan wisata berbasis air terjun serta warisan budaya.

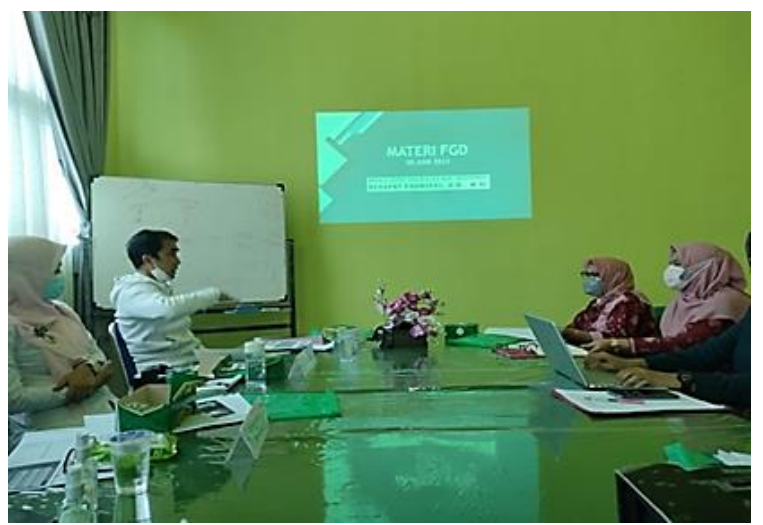

Gambar 3. Penjelasan materi oleh kepala Dinas Pariwisata Kabupaten Pesawaran Elsafri Fahrizal, S.H., M.Si. 
Destinasi pariwisata dikembangkan atas dasar kemamapuan daya tarik wisata yang perkembangannya secara sinergis dengan pengembangan fasilitas wisata, fasilitas umum, aksesibilitas/fasilitas dan pemberdayaan masyarakat dalam suatu konteks yang utuh dan berkelanjutan. Dalam proses pengembangan destinasi pariwisata, ada beberapa kemampuan yang dimiliki sekaligus sebagai kekuatan Indonesia guna mengembangkan destinasi pariwisata yang berdaya saing dan berkesinambungan (Nurhasanah, 2017).

Hal serupa juga terjadi di Kabupaten Pesawaran yang mempunyai makna strategis guna mengembangkan wisata bahari sebab ini perbatsannya langsung dengan Teluk Ratai, sehingga mempunyai kemampuan sumberdaya alam seperti pantai mangrove, berpasir, dan jasa-jasa lingkungan lain yang mempunyai kemmapuan untuk mengembangkan wisata bahari seperti potensi wisata mangrove, wisata pantai, dan wisata bahari yang bermacammacam dan menarik. Kabupaten Pesawaran mempunyai garis pantai sepanjang 96 km, yang terdiri dari Teluk Ratai perbatasan langsung dengan Selat Sunda dan mempunyai gugus pulau-pulau sebanyak 37 pulau (Pemda Pesawaran, 2016). Gugus pulau ini menyebar di Kecamatan Teluk Pandan, Marga Punduh, Punduh Pidada, dan Padang Cermin. Selanjutnya, Kabupaten Pesawaran mempunyai nilai yang cukupdalam wisata bahari yang penting utnuk dikembangkan (Pemda Pesawaran, 2016). Berdasarkan pemaparan materi dari Bapak Fisky Virdous, S. Hut., selaku Kepala Bappeda Kabupaten Pesawaran, petuntuk mengembangkan kawasan pariwisata pesisir serta bahari Kabupaten Pesawaran terletak di bagian Selatan. Hal ini sesuai dengan ketentuan Pasal 37 Perda Nomor 6 Tahun 2019 tentang RTRW Kabupaten Pesawaran Tahun 2019-2039.

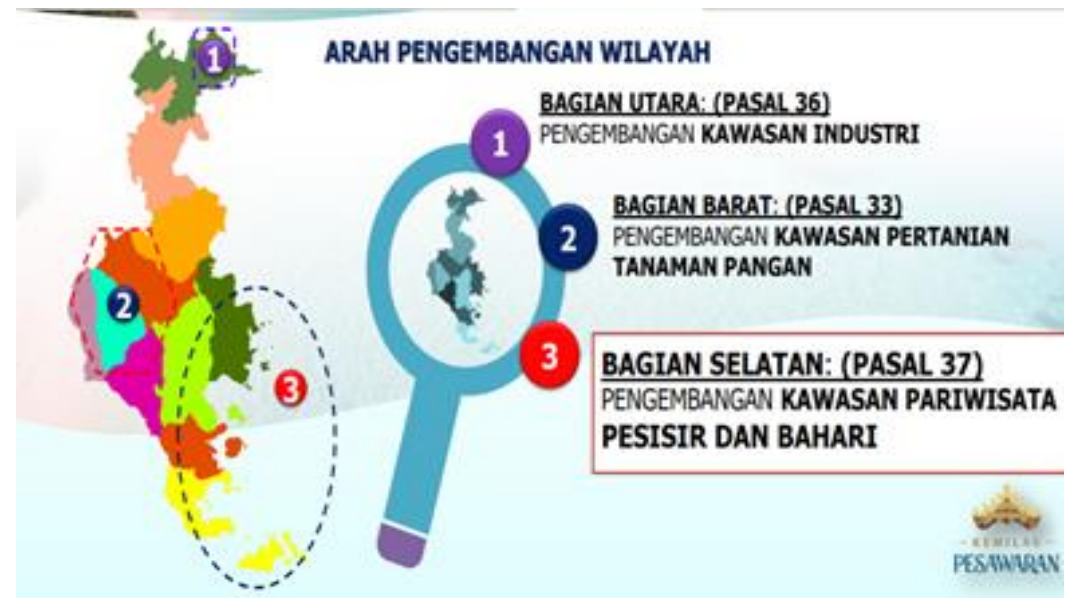

Gambar 4. Arah pengembangan wilayah Kabupaten Pesawaran

Selanjutnya berdasarkan Data Dinas Pariwisata hingga Tahun 2021, Kabupaten Pesawaran tercatat mempunyai beberapa obyek wisata bahari yang menyebar di berbagai 
gugus-gugus pulau yang terdapat pada Kabupaten Pesawaran (Alvi, 2018). Beberapa obyek wisata bahari Kabupaten Pesawaran lebih lanjut akan diuraikan pada tabel 1 .

Tabel 1. Destinasi wisata Kabupaten Pesawaran

\begin{tabular}{llll}
\hline No & $\begin{array}{c}\text { Destinasi } \\
\text { Wisata }\end{array}$ & \multicolumn{1}{c}{ Deskripsi } & Dokumentasi \\
& & $\begin{array}{l}\text { Hutan mangrove } \\
\text { Petengoran mempunyai }\end{array}$ \\
& Hutan Mangrove & $\begin{array}{l}\text { luas sekitar 113 hektar. } \\
\text { Dan telah di sahkan } \\
\text { dalam Peraturan Desa } \\
\text { Petengoran di } \\
\text { Desa Gebang }\end{array}$ & Tahun 2016. \\
& &
\end{tabular}

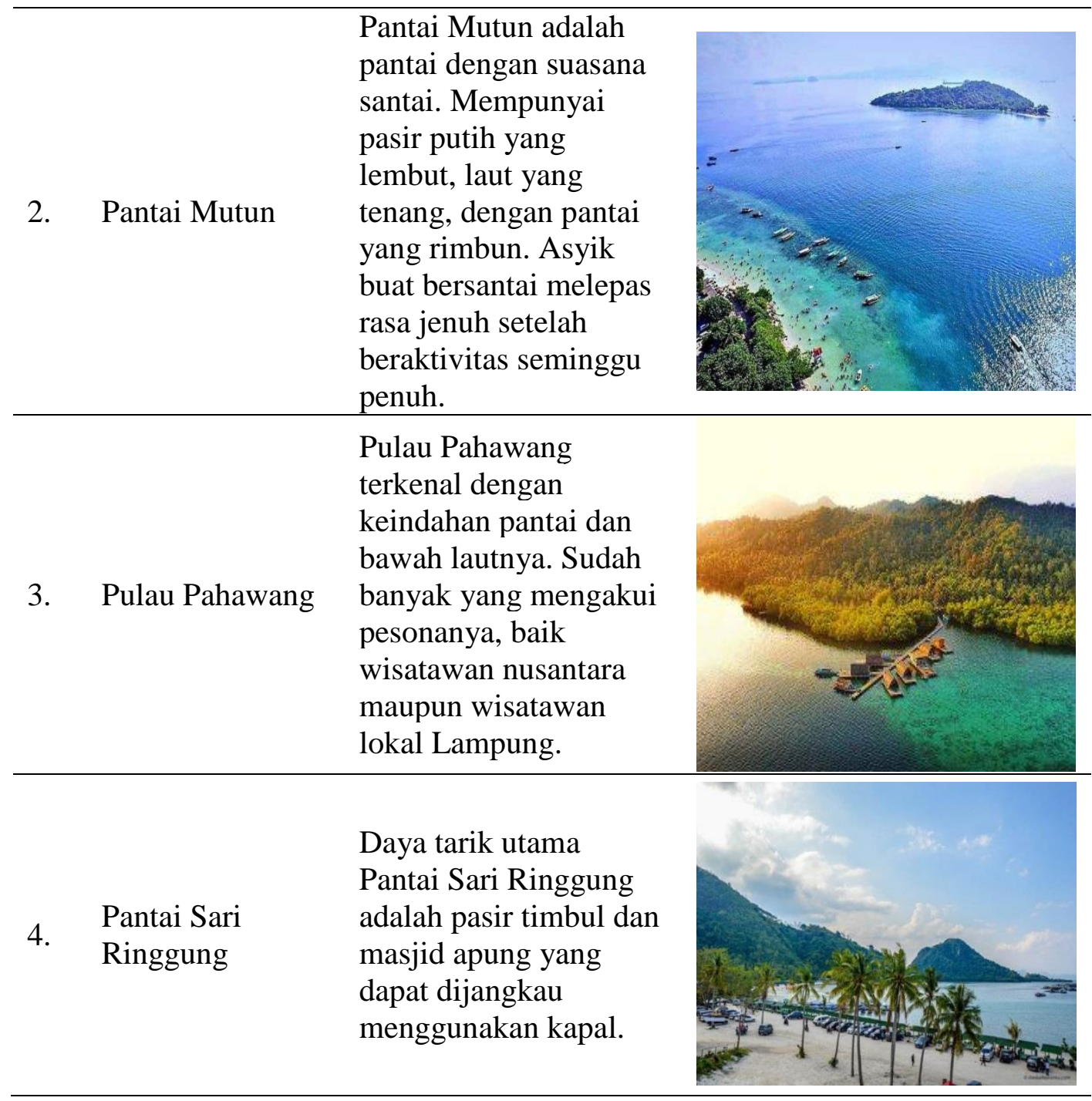

Masih maraknya kasus tindak pidana destructive fishing menuntut kebijakan hukum pidana pada sektor perikanan guna bisa menegakkan hukum pidana secara pasti, sehingga setiap pelaku yang melaksankan penangkapan ikan dengan cara yang tidak diperbolehkan 
khususnya destructive fishing bisa dipidana (Widyatmojo dkk, 2016). Ketetapan dalam pidana di bidang perikanan mempunyai peran sebagai pengendali dalam memanfaatkan potensi perikanan sertaperlindungan terhadap ekosistemnya sumber daya perikanan. Secara umum kebijakan hukum bertujuan guna mencegah dan memberikan efek jera bagi pelaku tindak pidana di bidang perikanan khususnya destructive fishing (Anwar, 2020). Dengan adanya kebijakan hukum pidana terhadap pelaku destructive fishing diharapkan dapat meminimalisir dan mengurangi angka tindak pidana di bidang perikanan. Pasal 84 dan Pasal 85 Undang-Undang Nomor 31 Tahun 2004 juncto Undang-Undang Nomor 45 Tahun 2009 tentang Perikanan adalah Perumusan kebijakan hukum pidana dalam penanggulangan destructive fishing.

Praktik destructive fishing tidak hanya merusak biodata dan ekosistem laut, akan tetapi juga berdampak buruk pada sektor pariwisata khususnya di Kabupaten Pesawaran. Dalam diskusi pada forum sosialisasi dan FGD di Dinas Pariwisata Kabupaten Pesawaran, beberapa narasumber yang mewakili beberapa instansi terkait mengemukakan bahwa dampak destructive fishing terhadap sektor pariwisata di Kabupaten Pesawaran ialah:

1. Kerusakan terumbu karang sehingga mengurangi daya tarik obyek wisata bawah laut;

2. Mengurangi dan menghilangkan berbagai jenis dan ukuran ikan;

3. Mengurangi stok ikan yang menyebabkan kelangkaan ikan;

4. Kenaikan harga ikan konsumsi dan ikan hias;

5. Pencemaran perairan pesisir; dan

6. Menimbulkan risiko kesehatan pada wisatawan saat mengkonsumsi ikan hasil destructive fishing.

Berikut penulis sajikan dalam bentuk tabel permasalahan yang ada, solusi yang diberikan dan hasil yang di capai dari pengabdian pada tabel 2.

Tabel 2. Permasalahan yang ada, solusi yang diberikan dan hasil yang di capai dari pengabdian

\begin{tabular}{clll}
\hline $\begin{array}{c}\text { Objek } \\
\text { Pengabdian }\end{array}$ & \multicolumn{1}{c}{ Permasalahan } & \multicolumn{1}{c}{ Solusi } & \multicolumn{1}{c}{ Luaran } \\
\hline & Kurangnya pengetahuan & Masyarakat perlu & Mitra memahami \\
& masyarakat mengenai & mendapat informasi & dampak destructive \\
dampak destructive & mengenai dampak & fishing terhadap \\
& fishing terhadap & destructive fishing & keberlanjutan \\
& keberlanjutan ekosistem & bagi keberlanjutan & ekosistem di \\
\hline
\end{tabular}




\begin{tabular}{|c|c|c|c|}
\hline \multirow{3}{*}{$\begin{array}{l}\text { Dinas } \\
\text { Pariwisata } \\
\text { Kabupaten } \\
\text { Pesawaran dan } \\
\text { masyarakat } \\
\text { nelayan } \\
\text { Kabupaten } \\
\text { Pesawaran }\end{array}$} & $\begin{array}{l}\text { di perairan dan } \\
\text { pariwisata bahari }\end{array}$ & $\begin{array}{l}\text { ekosistem di } \\
\text { perairan dan } \\
\text { pariwisata bahari }\end{array}$ & $\begin{array}{l}\text { perairan dan } \\
\text { pariwisata bahari }\end{array}$ \\
\hline & $\begin{array}{l}\text { Minimnya pengetahuan } \\
\text { mengenai peraturan, } \\
\text { pengawasan dan } \\
\text { pengelolaan pariwisata } \\
\text { bahari yang } \\
\text { berkelanjutan }\end{array}$ & $\begin{array}{l}\text { Masyarakat } \\
\text { membutuhkan } \\
\text { informasi mengenai } \\
\text { peraturan, } \\
\text { pengawasan dan } \\
\text { pengelolaan } \\
\text { pariwisata bahari }\end{array}$ & $\begin{array}{l}\text { Mitra memahami } \\
\text { peraturan, } \\
\text { pengawasan dan } \\
\text { pengelolaan } \\
\text { pariwisata bahari } \\
\text { yang berkelanjutan }\end{array}$ \\
\hline & $\begin{array}{l}\text { Masyarakat belum } \\
\text { memahami mengenai } \\
\text { teknologi penangkapan } \\
\text { ikan ramah lingkungan }\end{array}$ & $\begin{array}{l}\text { Masyarakat perlu } \\
\text { memahami } \\
\text { teknologi } \\
\text { penangkapan ikan } \\
\text { ramah lingkungan } \\
\text { dan perikanan } \\
\text { berkelanjutan }\end{array}$ & $\begin{array}{l}\text { Mitra menggunakan } \\
\text { teknologi } \\
\text { penangkapan ikan } \\
\text { ramah lingkungan } \\
\text { dan perikanan } \\
\text { berkelanjutan }\end{array}$ \\
\hline
\end{tabular}

Kondisi di atas, sangat mempengaruhi perkembangan di sektor pariwisata. Banyak spot-spot di wilayah perairan Provinsi Lampung khususnya di Kabupaten Pesawaran, menjadi trending di kalangan wisatawan domestik maupun internasional. Untuk itu diperlukan peran serta pemerintah bersama masyarakat, dalam perlindungan dan pengelolaan pariwisata bahari dari oknum pelaku destructive fishing. Langkah tersebut diantaranya dengan digiatkannya pembinaan dan informasi mengenai pentingnya menjaga ekosistem laut. Berdasarkan hasil diskusi dengan narasumber Dinas Perikanan Kabupaten Pesawaran, upaya lain yang dapat dilakukan untuk mencegah praktik destructive fishing diantaranya:

1. Melakukan sosialisasi secara berkala melalui POKDARWIS, POKMASWAS, dan KUB;

2. Melaporkan segala bentuk destructive fishing ke Dinas Perikanan atau penegak hukum;

3. Memberikan informasi dan wawasan kepada wisatawan mengenai pentingnya menjaga kelestarian biota laut;

4. Memberikan bantuan sarana komunikasi dan ABPI yang dibutuhkan nelayan;

5. Memberikan stimulus alat tangkap ramah lingkungan; dan

6. Pembentukan POKMASWAS pada setiap desa bekerjasama dengan PSDKP Provinsi Lampung. 
Lebih lanjut destructive fishing dapat dikurangi atau diminimalisir melalui pemasangan apartemen ikan, penanaman dan rehabilitasi terumbu karang, rehabilitasi mangrove, restocking, dan mengganti souvenir benda hidup ke benda mati untuk wisatawan. Menurut Kepala BAPPEDA Kabupaten Pesawaran, langkah-langkah pencegahan destructive fishing sebagaimana diuraikan di atas telah dilakukan. Upaya meminimalisasi penangkapan ikan yang tidak ramah lingkungan di Kabupaten Pesawaran antara lain:

1. Memberikan dukungan kegiatan kepada HNSI Kabupaten Pesawaran;

2. Pemberdayaan Kelompok Sadar Wisata (POKDARWIS) Kabupaten Pesawaran mengenai bahaya praktik destructive fishing; dan

3. Penyadaran tentang lingkungan melalui Kelompok Sadar Lingkungan (POKDARLING).

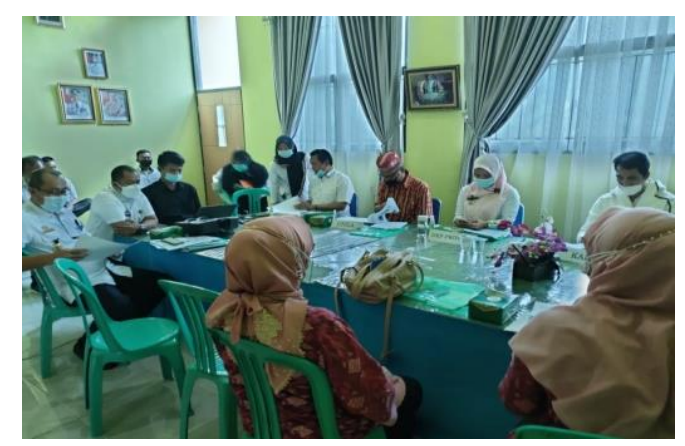

Gambar 5. Suasana diskusi dan tanya jawab dengan narasumber

Hukum pidana berfungsi sebagai ultimum remedium (obat terkahir), dalam penanggulangan destructive fishing (Shafira dkk, 2021). Perlu upaya non penal dengam melibatkan masyarakat dalam menanggulangi praktik destructive fishing (Shafira, \& Mashuril Anwar, 2021), terutama di Kabupaten Pesawaran. Keterlibatan masyarakat adalah suatu keniscayaan dalam mewujudkan pengelolaan pariwisata bahari berkelanjutan (Anwar \& Maya Shafira, 2020). Sedangkan pemerintah yang mempunyai peran dalam hal ini penting unutk melegtimasi kebijakan yang bisa mendukung pariwisata bahari Kabupaten Pesawaran dengan pendapat-pendapat dari masyarakat lokal yang memang paham benar apa saja kekurangan mereka. Berdasarkan isu-isu strategis pengelolaan pariwisata bahari Kabupaten Pesawaran tersebut, dirancang sebuah contoh dalam mengembangkan pariwisata bahari yang berkesinambungan dan berbasis masyarakat. Model tersebut dapat dilihat pada Gambar 6. 


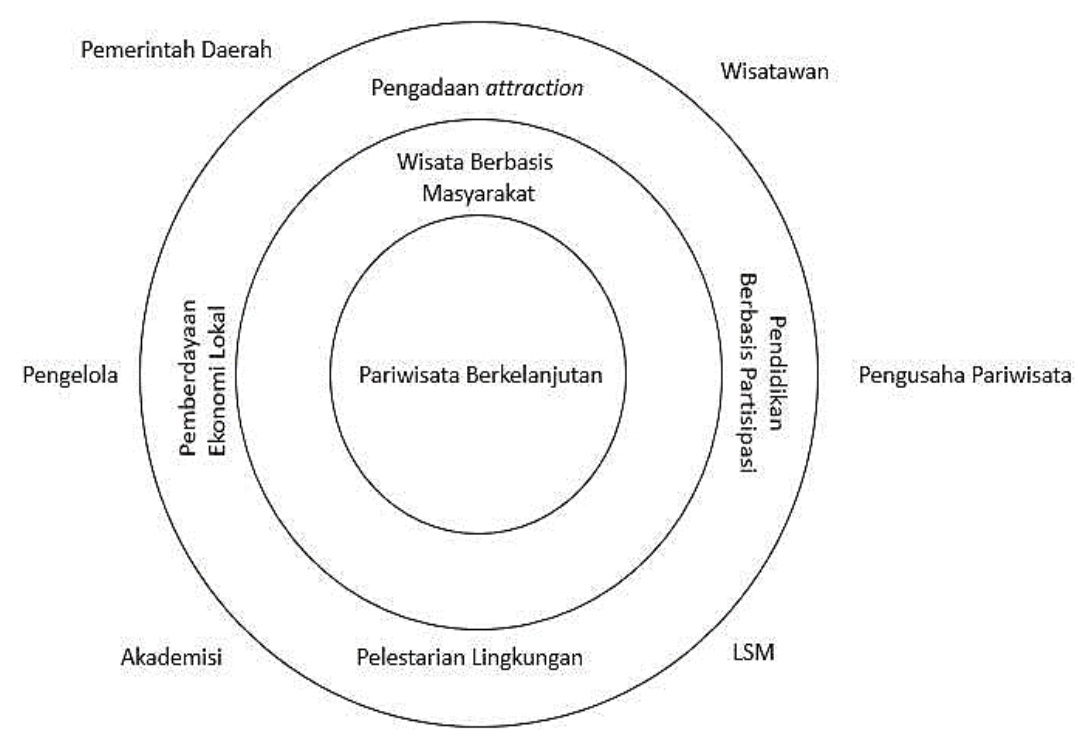

Gambar 6. Model Pengembangan Pariwisata Berkelanjutan yang dapat diterapkan di Pulau Pahawang (Nurhasanah, 2017)

\section{Faktor Pendukung dan Penghambat Kegiatan}

Terlaksananya kegiatan pengabdian kepada masyarakat ini tidak terlepas dari beberapa faktor pendukung, antara lain:

1. Dukungan pendanaan dari Lembaga Penelitian dan Pengabdian Kepada Masyarakat (LPPM) Universitas Lampung;

2. Kebijakan Kepala Dinas Pariwisata Kabupaten Pesawaran yang telah menyetujui pelaksanaan kegiatan;

3. Narasumber yang berkompeten;

4. Tanggapan positif, sikap terbuka, serta partisipasi yang baik dari berbagai narasumber yang berasal dari beberapa instansi terkait;

5. Tersedianya fasilitas yang menunjang terlaksananya kegiatan; dan

6. Kekompakan, kerjasama, dan koordinasi yang baik tim pengabdian dalam mempersiapkan kegiatan.

Selain faktor pendukung, ada pula faktor penghambat dalam pelaksanaan kegiatan. Hambatan-hambatan yang ditemui tidak berpengaruh banyak pada pelaksanaan kegiatan. Namun perlu mendapat perhatian sebagai bahan evaluasi untuk memperbaiki kegiatan mendatang. Hambatan-hambatan tersebut diantara pelaksanaan kurang tepat dengan waktu yang telah ditentukan karena beriringan dengan jam kerja para narasumber. 


\section{SIMPULAN}

Kabupaten pesawaran memiliki beberapa kawasan wisata yang berbasis pantai, kuliner, kerajinan, kawasan wisata berbasis bahari dan warisan budaya, serta kawasan wisata berbasis air terjun. Arah pengembangan kawasan pariwisata pesisir dan bahari Kabupaten Pesawaran terletak di bagian Selatan. Dampak destructive fishing terhadap sektor pariwisata di Kabupaten Pesawaran ialah kerusakan ekosistem dan berbagai biodata laut yang mengurangi daya tarik pariwisata. Kegiatan ini telah memberikan berbagai masukan atau udekuakasi terkait penanggulangan tindak pidana destructive fishing, guna keberlanjutan pengelolaan pariwisata bahari di Kabupaten Pesawaran tetap terjaga ekosistemnya

\section{UCAPAN TERIMAKASIH}

Tim pengabdian kepada masyarakat mengucapkan terima kasih kepada Lembaga Penelitian dan Pengabdian Kepada Masyarakat (LPPM) Universitas Lampung, yang telah mendanai kegiatan. Selanjutnya terima kasih kepada Dinas Pariwisata Kabupaten Pesawaran, yang telah bersedia bermitra dalam pelaksanaan kegiatan.

\section{DAFTAR PUSTAKA}

Alvi, Nava Neilulfar, Isye Susana Nurhasanah dan Citra Persada. (2018). Evaluasi Keberlanjutan Wisata Bahari Pulau Pahawang Kabupaten Pesawaran. Jurnal Plano Madani, 7(1), 59-68.

Anwar, Mashuril dan Maya Shafira. (2020). Harmonisasi Kebijakan Pengelolaan Lingkungan Pesisir Lampung dalam Rezim Pengelolaan Berbasis Masyarakat. Jurnal Hukum Lingkungan Indonesia, 6(2), 266-287.

Anwar, Mashuril. (2020). Kebijakan Hukum Pidana Dalam Penanggulangan Destructive Fishing Pada Rezim Pembangunan Berkelanjutan. Jurnal Samudra Keadilan, 15(2), 237-250.

Dinas Pariwisata Kabupaten Pesawaran. (2015). Rencana Induk Pariwisata Daerah (RIPPDA) Kabupaten Pesawaran 2017-2031. Kabupaten Pesawaran: Dinas Pariwisata Kabupaten Pesawaran.

Hall, C. M. (1999). Tourism and Politics: Policy Power and Place. New York: John Wiley \& Sons.

Musdalifah. (2017). Tinjauan Yuridis Terhadap Pengeboman Ikan Di Laut Wilayah Hukum Polres Pangkajenne dan Kepulauan Perspektif Hukum Islam. Skripsi Sarjana Universitas Islam Negeri Alauddin Makassar, Makassar. 
Nurhasanah, Isye Susana, Nava Neilulfar Alvi, dan Citra Persada. (2017). Embracing Sustainable Tourism through Local Community's Empowerment in Pahawang Island, Pesawaran, Lampung Province. Jurnal Tata Loka, 19(2), 59-63.

Pemda Pesawaran. (2016). Data Sektor Kelautan dan Perikanan. Pesawaran: Pemerintah Daerah Kabupaten Pesawaran.

Shafira, Maya dan Mashuril Anwar. (2021). Destructive Fishing Treatment Policy Based on Community Supervision in Lampung Province. (Proceedings of the 2nd International Conference on Fundamental Rights, I-COFFEES 2019, 5-6 August 2019, Bandar Lampung, Lampung, Indonesia.

Shafira, Maya dkk. (2021). Illegal Fishing: Optimalisasi Kebijakan Penegakan Hukum Pidana sebagai Primum Remedium. Wawasan Yuridika, 5 (1), 40-59.

Widyatmojo, Ruth Shella, dkk. (2016). Penegakan Hukum Terhadap Tindak Pidana Pencurian Ikan (Illegal Fishing) di Wilayah Zona Ekonomi Eksklusif (Studi Kasus: Putusan Pengadilan Negeri Ambon Nomor 1/Pid. Sus/PRK/2015/PN.AMB). Diponegoro Law Journal, 5(3), 1-14. 